\title{
Parent-Adolescents Conflicts and its Relation with their School Achievement and Self-esteem
}

\author{
Marzoka A. Gadallah, Atyat M. Hassan, Safaa A. Kotb \& Nadia A. Abd EL-Hameed. \\ Assissetent Professor of Pediatric Nursing, Faculty of Nursing, Assiut University, Egypt \\ Lecture of Pediatric Nursing, Faculty of Nursing, Assiut University, Egypt. \\ Professor of Community Health Nursing, Faculty of Nursing, Assiut University, Egypt \\ Lecturer of Psychiatric Nursing, Faculty of Nursing, Assiut University, Egypt
}

\begin{abstract}
Background: Parent-adolescent conflict is complex and multifaceted construct as it includes any differences of opinions, whether it is negative or positive between parents. This study aimed to identify the parent-adolescents conflicts and its relation with their school achievement and self-esteem. A descriptive correlational research design was used. 1018 adolescents were recruited in this study. It was conducted at eight governmental preparatory schools, four schools in urban areas and four in rural areas in assiut governorate, Upper Egypt. Four tools were used for this study as demographic questionnaire for the adolescents and their parents, parent-adolescent issues checklist, adolescent self-esteem scale and adolescents' school achievement. Results indicated that the majority of the studied adolescents $(93.6 \%)$ had conflict with their parents. The greater the conflict between adolescents and their parents, the higher the school achievements occurred, $\mathrm{p}=0.004$. But there was no statistically significant relation between the adolescents' self-esteem and parent-adolescent conflict. Conclusion, the majority of adolescents had higher frequency of conflict issues but intensity of conflict was not severe with their parents. Parent-adolescent conflict-had a positive effect on adolescent School achievement. The present study Recommended that, parents should be aware of physical, cognitive and psychosocial changes and needs of the adolescents to deal with their children positively. Periodical assessment should be done for self-esteem to all children in schools for early detection and management of any problem.
\end{abstract}

Key words:Parent-Adolescent Conflicts, School Achievement \& Self-esteem.

\section{Introduction}

Adolescence is a stage characterized by unique changes in physical growth and cognitive, emotional, social and self-definitional development. Also, it is frequently sensed as a challenging period of life for the adolescent and their family (Steinberg \& Silk, 2002).

Conflict is defined as any disagreement, difference and argument about an issue that rises in family life. However, the Parent-adolescent conflict is complex and multifaceted construct as it includes any differences of opinions, whether it is negative or positive between parents (Kouros et al., 2010). It is defined as a dyadic, interpersonal situation including obvious behavioral disapproval as disputes, disagreements and squabbles (Melching Jessica, 2011). Therefore communication and conflict between adolescent and their parents often encompass renegotiating rules, roles and relationships regarding everyday topics as activities, friends, responsibilities and school (Shearman \& Dumlao 2008).

Adolescents' intensifying struggling about autonomy can be a factor that increases parent-adolescent disagreement through early adolescence and heighten a negative impact of conflicts during middle adolescence. The main cause of conflicts between the parents and adolescents is the discrepancy between their expectations as regard proper behavior and the suitable time of turns in authority, independence, and duties (Pinquart \& Silbereisen, 2002 \& Branje et al., 2009).

Some conflicts with parents can be considered a normal part of family relations throughout adolescence and it has a well-defined function in the adolescent development of autonomy and individuation (Steinberg, 2001). While, when a lot of and excessive frequent conflicts may be a predisposing factor for adolescent psychosocial adjustment and well-being (Branje et al., 2009).

Wingat (2004), Shehata \& Ramadan (2010) \& Shibeshi, (2015) stated that parents' socialization manner in their children might also be a factor in initiating conflict between them. Likewise, Renk \& Simpson (2005), added that disagreements upon topics like daily tasks, freedom, rights and relationships are indicators about young adults' desire for increased autonomy and independence from their parents. While conflicts over topics as religious, political, or social occur less frequently they considered it as sensitive topics. 
Similarly, Nebel-Schwalm (2006), revealed that school achievement was an important sign of change and modification as it has been related to many factors like styles of parents, parents' involvement, conflict within the family, school and homework activities, intellectual capacity and socio-economic condition. In addition; Unger et al., (2000), found that marital conflict could be a factor affect on parent-adolescent conflict and academic achievement.

Academic achievement may be a cause of stress and conflict in families as conflict can get up when adolescent wasn't doing as well in school as their parents would like (Onongha, 2015),

Higher levels of parent-adolescent conflict could have a negative impact on adolescents' and parents' psychological well-being and their satisfaction of life. This could cause higher levels of internalizing problems such as low self-esteem (Smetana et al., 2006 \& Pajckic, 2013).

Self-esteem is evaluated by a number of essential psychological phenomena, both positive and negative. High self-esteem has been linked with productive coping strategies, enhanced motivation and positive emotional state. A person with low selfesteem would involve more conflicts and poor coping skills to life stresses (Yaacob, 2006). Deshpande and Chhabriya (2013), stated that due to the generation gap between parents and their adolescents and inability of parents to appreciate their adolescents, conflicts develop. Also, reported that mild punishment from parents can result in high selfesteem in adolescents' as they view their parents as their caretaker.

Pediatric nurses play an important role in parental education about needs, problems, causes that could increase parent-adolescent conflict and developmental changes that the adolescents would have and in facilitating parent/youth relationships and how to resolve these conflicts (American Nurses Association and Society of Pediatric Nurses, 2003)

\section{Significance of the study}

Twenty-five percent of the total populations in Egypt were adolescents UNICEF, (2011). According to the age of highest disagreement begin when the young adults were between 13 - 16 years old; that is during the years of beginning liberation from parental dominance. This increase may be due to a number of factors; the puberty's biological conversions, intellectual variations including increased idealism and logical reasoning, social changes focused on autonomy and individuality, maturational changes in parents, and expectations that are violated by parents and adolescents. The adolescent compares her/ his parents to an ideal standard and then criticizes their flows (Elemary et al., 2016).

\section{Aim of the study}

The present study aimed to identify the parentadolescent conflicts and its relation with their school achievement and self-esteem.

\section{Study questions}

- What are the frequencies and intensity of parentadolescent conflicts?

- What is the relationship between parent-adolescent conflicts and school achievement?

- What is the correlation between parent-adolescent conflicts and self-esteem?

- What are association between Parent-adolescent conflicts with characteristics of adolescents and their parent?

\section{Conceptual framework}

Variables

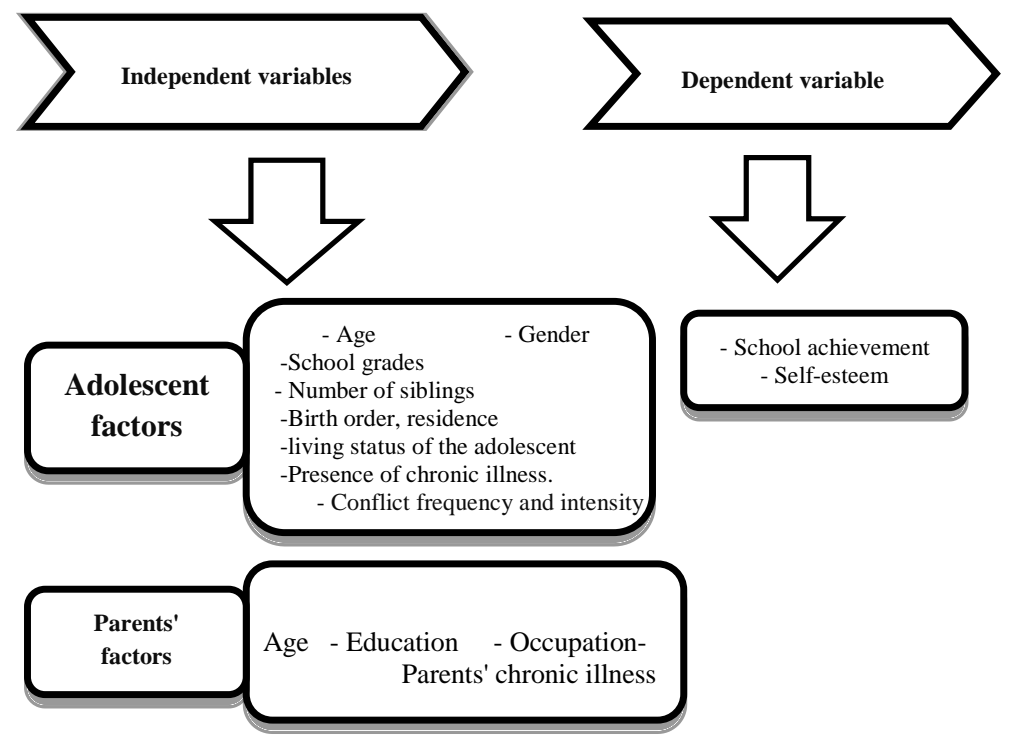

\section{Subjects \& method Study design}

A Descriptive correlational research design was used for this study.

\section{Setting}

It was conducted at eight governmental preparatory schools, four schools in urban areas and four in rural areas in Assiut governorate; Upper Egypt.

\section{Target Population}

A representative sample of adolescents was recruited in this study. The researchers followed a stratified sampling. A list of all governmental preparatory schools was obtained from the directorate of education in Assiut governorate; Upper Egypt. One school was selected randomly from each direction in 
urban and rural areas. From each school, two classes for each grade were chosen randomly. Each class included about (30-40) students. The researchers interviewed all children to fill the sheet in the selected classes. The total sample was 1018 adolescents.

\section{Tools of data collection}

\section{Four tools were used for this study}

Tool I: Demographic questionnaire for adolescent and their parents which included two parts

Part one: Personal data for adolescent as gender, age, school grades, the number of siblings, birth order, residence, the living status of the adolescent and presence of chronic illness.

Part two: Personal data for parents as age, history of chronic illness, education and occupation.

Tool II: Parent-Adolescent issues checklist. This scale developed by Robin and Foster (1989) to assess frequency and intensity of the parentadolescent conflict. It consists of forty-four items covering conflict topics. Adolescents point to whether or not each of the issues (e.g., "performing homework," "sleeping time") had been the topic of conflict with their parents during the previous four weeks. Their answers were computed in two ways:

- Frequency of conflict: Count the number of issues marked "yes." when adolescents circle 13 or more items "yes" considered had frequent conflict. Higher scores indicate higher levels of conflict frequency.

- Intensity of issues: For issues marked "yes," add intensity ratings and divide by the number of issues marked "yes" to obtain mean intensity rating. The intensity of conflict was calculated by summing the products of each conflict intensity topic (based on a 5-point Likert scale ranging from 1= "very calm" to 5= "very angry"),. This score adjusts for the possibility that highly intense conflicts might be related to frequently discussed issues (Printz et al., 1979). When adolescents had a mean intensity rating of 1.7 or higher considered had conflict intensity. Higher scores indicate more intense conflicts and lower scores indicate less intense conflicts.

The scale translated into Arabic by the researchers. the content validity was done by 5 experts (two in the pediatric nursing field, one in community health nursing and two in psychiatric nursing) the content validity index was 0.73 and reliability were tested, by using Cronbach's alpha and it was $\mathrm{r}=0.83$

Tool III: Adolescent Self-Esteem Scale. The original scale was constructed by Rosenberg SelfEsteem Scale (1965). It includes ten items on a fourpoint scale from "strongly agree $=4$ " to "strongly disagree $=1$ ". Final scores range from 10 to 40 . Higher scores represent higher levels of self-esteem and lower scores represent lower levels of selfesteem. The scale was reliable by using Cronbach's alpha values $r=0.88$.

Tool VI: Adolescents' Academic Achievement Tool (Dornbush et al., 1987), it was measured based on adolescents' self-reports on the most recent exam scores over the last year. Responses that best represented their school grades were indicated on the questionnaire (e.g., $5=$ "mostly excellent in different subjects (A's") to $1=$ "mostly failed in different subjects (F's"). Test-retest correlations for this measure range from .85 and .85 . Cronbach's alpha for this study was .73.

\section{Procedure}

\section{Method of data collection}

An official permission to collect data was obtained from the prime minister of education. Tool one was developed by the researchers and was tested for its content validity by five experts in the pediatric, community and psychiatric nursing field it was 0.9. Tool reliability was done by using Cronbach alpha coefficient, it was $\mathrm{r}=0.98$. A written consent was obtained from the studied adolescents to collect the data after explaining the purpose and the nature of the study.

A pilot study was carried on (10\%) of the adolescents .It was conducted to assess the clarity of the study tool and the time needed to fulfill the sheet. As the results of the pilot study, the necessary modifications were done (two items as "using the television" to "watching television and using social media" and "drinking beer or other alcoholic beverages" to "drinking beer" to match with our community tradition)..

The researchers interviewed the adolescents during classes of activities and physical exercise (PE).The researchers distributed the sheet for all adolescents and they were waiting for filling the sheet, the time needed about $45-60$ minutes for each class.

During the period of data collection; about (188) students refuse to participate in the study and about (200) students return the sheet with incomplete data and some of them were absent; these were excluded from the study. The data were collected during the period of four months from February to May 2016.

\section{Ethical considerations}

The research proposal was approved by Ethical Committee of the Faculty of Nursing. The-adolescent students were informed about the study and they were advised that; they were under no obligation to participate or not in the study and the study will not affect their education or assessment. Confidentiality and anonymity was assured. Adolescents had the rights to refuse to participate of the study without any rational. 


\section{Data management and statistical Analysis}

Data were coded, entered and cleaned using the Statistical Package for Social Science (SPSS Inc., Chicago, IL, USA) version 20. Data analysis was done in the form of univariate analysis: descriptive statistics (frequency \& percent for qualitative data, mean \pm SD for quantitative data). Bivariate analysis: cross tabulation. Chi-square test $\left(\mathrm{X}^{2}\right)$ and correlation coefficient were used to test the difference between the proportions of qualitative data. Statistical significance level was considered when p-value $<0.05$ for all statistical tests.

\section{Results}

Table (1): Rank Order according to the Highest and lowest topics' Frequency and intensity of Discussion over Last 4 Weeks.

\begin{tabular}{|c|c|c|c|}
\hline \multirow{2}{*}{ Highest topics } & \multicolumn{2}{|c|}{ Frequency } & \multirow{2}{*}{$\begin{array}{c}\text { Intensity } \\
\text { Mean } \pm \text { SD } \\
\end{array}$} \\
\hline & No & $\%$ & \\
\hline 1. Making too much noise at home & 779 & 76.5 & $1.8 \pm 1.6$ \\
\hline 2. Watching television or using social media & 757 & 74.4 & $1.6 \pm 1.5$ \\
\hline 3. $\quad$ Cleaning bedroom & 756 & 74.3 & $1.4 \pm 1.4$ \\
\hline 4. $\quad$ Sleeping time & 746 & 73.3 & $1.3 \pm 1.2$ \\
\hline 5. Arranging clothes & 740 & 72.7 & $1.3 \pm 1.3$ \\
\hline 6. Performing homework & 737 & 72.4 & $1.3 \pm 1.4$ \\
\hline 7. Friends should they have & 733 & 72.0 & $1.1 \pm 1.1$ \\
\hline 8. Fighting with brothers and sisters & 731 & 71.8 & $1.9 \pm 1.8$ \\
\hline 9. Allowance & 727 & 71.4 & $1.0 \pm 1.1$ \\
\hline 10. Selection of new clothes & 704 & 69.2 & $1.1 \pm 1.0$ \\
\hline \multicolumn{4}{|l|}{ Lowest topics } \\
\hline 11. Using drugs & 503 & 49.4 & $0.8 \pm 1.2$ \\
\hline 12. Earning money away from the house & 473 & 46.5 & $1.1 \pm 1.4$ \\
\hline 13. Bothering adolescent when he/she wants to be left alone & 464 & 45.6 & $0.8 \pm 1.3$ \\
\hline 14. Going on dates & 455 & 44.7 & $1.0 \pm 1.3$ \\
\hline 15. Buying games, toys, and other things & 436 & 42.8 & $0.7 \pm 1.1$ \\
\hline 16. Bothering parents when they want to be left alone & 433 & 42.5 & $0.8 \pm 1.3$ \\
\hline 17. Cursing & 408 & 40.1 & $0.9 \pm 1.5$ \\
\hline 18. Smoking/spit tobacco & 310 & 30.5 & $0.8 \pm 1.6$ \\
\hline 19. Drinking beer & 246 & 24.2 & $0.7 \pm 1.5$ \\
\hline
\end{tabular}




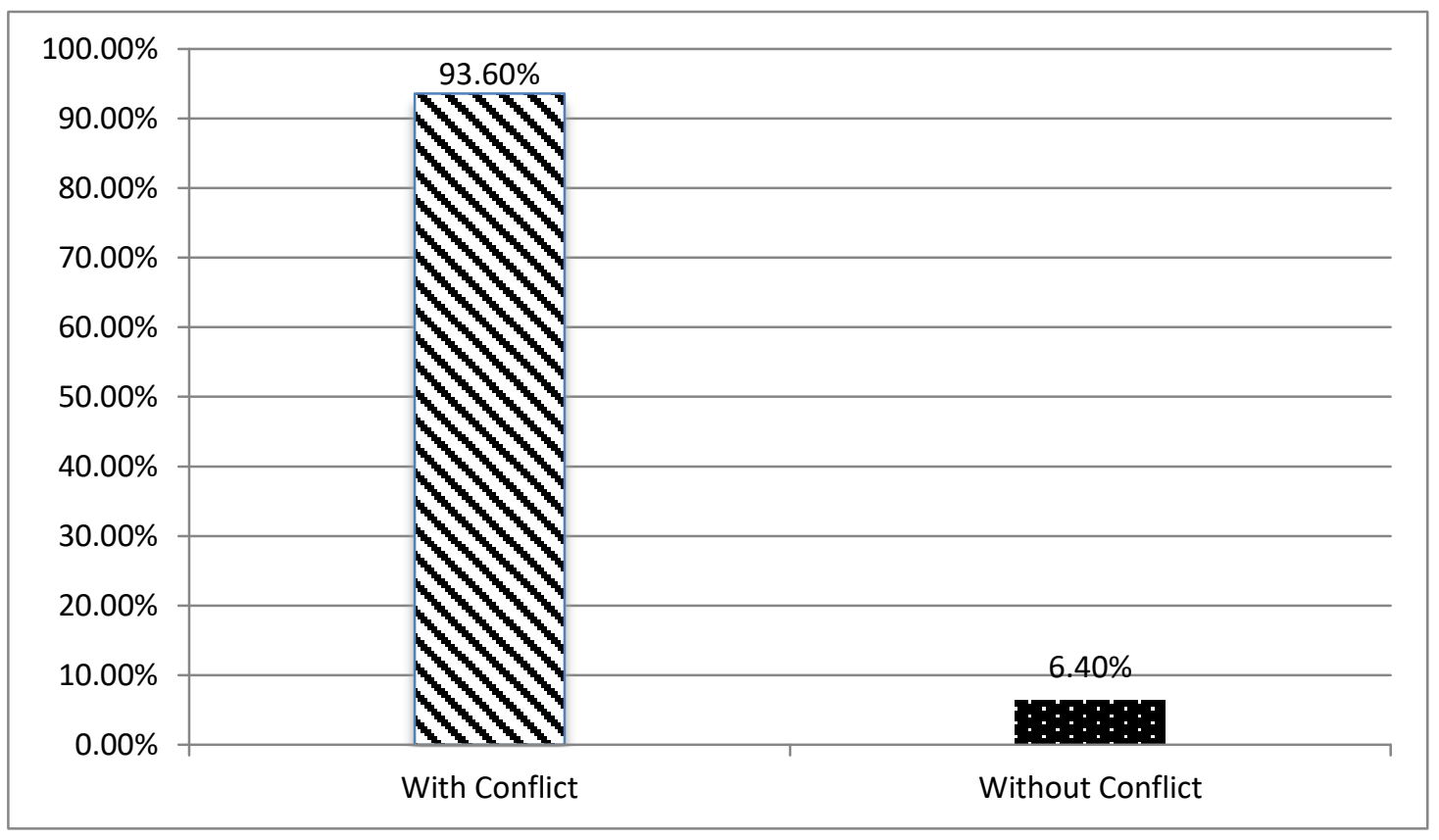

Figure (1): Percentage distribution of parent-adolescent conflict frequency.

Table (2) Relation between characteristics of studied adolescents and the experience of conflicts with their parents.

\begin{tabular}{|c|c|c|c|c|c|c|c|}
\hline \multirow{2}{*}{ Items } & \multirow{2}{*}{$\begin{array}{c}\text { Total } \\
(\mathrm{N}=1018)\end{array}$} & \multicolumn{2}{|c|}{ Conflict $n=953$} & \multicolumn{2}{|c|}{ No conflict $n=65$} & \multirow[t]{2}{*}{$\mathbf{X}^{2}$} & \multirow{2}{*}{$\begin{array}{c}\text { p- } \\
\text { value }\end{array}$} \\
\hline & & No & $\%$ & No & $\%$ & & \\
\hline \multicolumn{6}{|l|}{ School achievement } & \multirow{6}{*}{17.23} & \multirow{6}{*}{0.004} \\
\hline Most excellent & 363 & 325 & 89.5 & 38 & 10.5 & & \\
\hline Excellent and most very good & 301 & 286 & 95.0 & 15 & 5.0 & & \\
\hline Very good and most good & 175 & 169 & 96.5 & 6 & 3.5 & & \\
\hline Good and most pass & 126 & 123 & 97.6 & 3 & 2.4 & & \\
\hline Pass and most failed & 53 & 50 & 94.3 & 3 & 5.7 & & \\
\hline \multicolumn{6}{|l|}{ Residence. } & \multirow{3}{*}{8.38} & \multirow{3}{*}{0.004} \\
\hline Urban & 544 & 498 & 91.6 & 46 & 8.4 & & \\
\hline Rural & 474 & 455 & 96 & 19 & 4.0 & & \\
\hline \multicolumn{6}{|l|}{ Gender } & \multirow{3}{*}{3.26} & \multirow{3}{*}{0.05} \\
\hline Male & 494 & 470 & $(95.1)$ & 24 & 4.9 & & \\
\hline Female & 524 & 483 & 92.2 & 41 & 7.8 & & \\
\hline \multicolumn{6}{|l|}{ The living status of the child } & \multirow{5}{*}{8.79} & \multirow{5}{*}{0.04} \\
\hline $\begin{array}{l}\text { With his/her father due to } \\
\text { divorce or mother's death }\end{array}$ & 8 & 8 & 100 & 0 & 0.0 & & \\
\hline $\begin{array}{l}\text { With his/her mother due to } \\
\text { divorce or father's death }\end{array}$ & 45 & 44 & 97.8 & 1 & 2.2 & & \\
\hline With his/her parents & 810 & 749 & 92.5 & 61 & 7.5 & & \\
\hline $\begin{array}{l}\text { With his/her parents in the } \\
\text { family house }\end{array}$ & 155 & 152 & 98.1 & 3 & 1.9 & & \\
\hline
\end{tabular}

* Level of significance at $P=<0.05$. 
Table (3): Correlation between the characteristic of adolescents and their parents and Parent-adolescent conflict.

\begin{tabular}{|l|c|c|}
\hline \multicolumn{1}{|c|}{ Parent's adolescent characteristic } & \multicolumn{2}{c|}{ Parent's adolescent conflict } \\
\cline { 2 - 3 } & $\mathbf{r}$ & Significance \\
\hline Mother's age & 0.19 & 0.544 \\
\hline Father's age & $-.019-$ & 0.538 \\
\hline Mother's education & $-.028-$ & 0.378 \\
\hline Father's education & .015 & 0.636 \\
\hline Mother's occupation & $-.043-$ & 0.175 \\
\hline Father's occupation & .042 & 0.183 \\
\hline Parents' chronic illness (Yes) & 0.22 & 0.5 \\
\hline Residence. & .091 & 0.004 \\
\hline School grades( levels) & $-.122-$ & 0.000 \\
\hline Number of siblings & .045 & 0.156 \\
\hline Age/year & $-.088-$ & 0.005 \\
\hline Birth order & .066 & 0.039 \\
\hline Child chronic illness & $-.010-$ & 0.759 \\
\hline
\end{tabular}

Table (4): Relation between adolescents' self-esteem and parent-adolescent conflicts scores.

\begin{tabular}{|c|c|c|c|c|c|c|c|}
\hline \multirow{2}{*}{ Items } & \multirow{2}{*}{ Total } & \multicolumn{2}{|c|}{ Conflict $\mathbf{n = 9 5 3}$} & \multicolumn{2}{|c|}{ No conflict $\mathbf{n = 6 5}$} & \multirow{2}{*}{$\mathbf{X}^{\mathbf{2}}$} & \multirow{2}{*}{ P. value } \\
\cline { 3 - 7 } & & $\mathbf{N o}$ & $\mathbf{\%}$ & $\mathbf{N o}$ & $\mathbf{\%}$ & & \\
\hline Low self-esteem $(<\mathbf{2 0})$ & 387 & 357 & 92.2 & 30 & 7.8 & 0.57 & \multirow{2}{*}{0.3} \\
\hline High self-esteem(>20) & 631 & 596 & 94.5 & 35 & 5.5 & & \\
\hline
\end{tabular}

Table (5): Relation between school achievement, self-esteem and parent-adolescent conflicts.

\begin{tabular}{|c|c|c|c|c|c|c|c|}
\hline \multirow[b]{2}{*}{ Items } & \multirow[b]{2}{*}{ Total } & \multicolumn{4}{|c|}{ Level of self esteem } & \multirow{3}{*}{$\mathbf{X}^{2}$} & \multirow[b]{2}{*}{ P. value } \\
\hline & & \multicolumn{2}{|c|}{$\begin{array}{l}\text { Low level of self- } \\
\text { esteem } n=378\end{array}$} & \multicolumn{2}{|c|}{$\begin{array}{c}\text { High level of } \\
\text { self-esteem } \\
n=631\end{array}$} & & \\
\hline School achievement with conflict & & No & $\%$ & No & $\%$ & & \multirow{6}{*}{0.000} \\
\hline Most excellent & 325 & 144 & 44.3 & 181 & 55.7 & \multirow{5}{*}{0.143} & \\
\hline Excellent and most very good & 286 & 118 & 41.3 & 168 & 58.7 & & \\
\hline Very good and most good & 169 & 46 & 27.2 & 123 & 72.8 & & \\
\hline Good and most pass & 123 & 37 & 30.1 & 86 & 69.9 & & \\
\hline Pass and most failed & 50 & 12 & 24.0 & 38 & 76.0 & & \\
\hline \multicolumn{6}{|l|}{ School achievement without conflict } & \multirow{6}{*}{0.257} & \multirow{6}{*}{0.039} \\
\hline Most excellent & 38 & 22 & 57.9 & 16 & 42.1 & & \\
\hline Excellent and most very good & 15 & 4 & 26.7 & 11 & 73.3 & & \\
\hline Very good and most good & 6 & 3 & 50.0 & 3 & 50.0 & & \\
\hline Good and most pass & 3 & 1 & 33.3 & 2 & 66.7 & & \\
\hline Pass and most failed & 3 & 0 & 0.0 & 3 & 100 & & \\
\hline
\end{tabular}

A total of 1018 adolescents, aged from $12-15$ years with mean age $14.06 \pm 1.10$ were included in the study. Thirty-two of the adolescents were in grade one and $(36.9 \%)$ were in grade two. The first and second birth order constitutes three-fifths of studied sample $(60.7 \%)$ and about one-third of adolescents have 1-2 siblings. The mean of mothers' age was $39.11 \pm 5.51$ while the mean age of the fathers was
$46.56 \pm 6.76$. Thirty percent of mothers and more than one-third of fathers had higher education.

Table (1): Presents rank order according to the highest and lowest topics frequency and intensity of discussion over last four weeks. The table revealed that, the most common topics that increased incidence of conflict between adolescent and their parents were making too much noise at home 
(76.5\%), watching TV or using the internet (74.4\%), cleaning bedroom (74.3), sleeping time (73.3), arranging clothes $(72.7 \%)$, performing homework $(72.4 \%)$, friends should they have $(72.0 \%)$, fighting with brothers and sisters $(71.8 \%)$, allowance $(71.4 \%)$, and selection of new clothes (69.2\%). Regarding conflict intensity; making too much noise at home and fighting with brothers and sisters were the most intense topics with mean intensity $1.8 \pm 1.6$ and $1.9 \pm 1.8$ respectively.

While the lowest topics that increase incidence of conflict between adolescent and their parents were using drugs (49.4), earning money away from the house $(46.5 \%)$, bothering adolescent when he/she wants to be left alone (45.6\%), going on dates $(44.7 \%)$, buying records, games, toys, and other things $(42.8 \%)$, bothering parents when they want to be left alone $(42.5 \%)$, cursing $(40.1 \%)$, smoking/spit tobacco $(30.5 \%)$, and drinking beer $(24.2 \%)$.

Figure (1): Regarding percentage distribution of parent-adolescent conflict frequency. The figure indicated that the majority of adolescents (93.6\%) had conflict.

Table (2): Represented relation between characteristics of the studied adolescents and the experience of the conflicts with their parents. There was statistically significant difference between school achievement, gender, mother's occupation and parentadolescent conflict. The frequency of parentadolescent conflict would increase with studied adolescents who had higher scores of school achievement $(\mathrm{P}<0.004)$. In addition; male gender, rural areas and the adolescents' who living either with their fathers or mothers were factors that increase parent-adolescent conflict with statistically significant $\quad(\mathrm{P}<0.004, \quad \mathrm{P}<\quad 0.05$ and $\quad \mathrm{P}<0.03$ respectively).

Table (3): Illustrated correlation between the characteristic of adolescents and their parents and parent-adolescent conflict. There was statistically significant positive correlation between the residence, birth order with the parents-adolescent conflict ( $\mathrm{R}$ 0,004 and 0.039 respectively) while a statistically negative correlation found between the adolescents' school grades, ages with the parentsadolescent conflict (R 0,000 and 0.005 respectively)

Table (4): Revealed the relation between adolescents' self-esteem and parent-adolescent conflicts scores. There was no statistically significant relation between the adolescents' self-esteem and parent-adolescent conflict.

Table (5): Showed relation between school achievement, self-esteem and parent-adolescent conflicts. There was highly statistically significant relation between school achievement of adolescent and level of self-esteem $(\mathrm{P}<0.000$ and $\mathrm{P}<0.039$ respectively). The higher the percentage of school achievement among adolescent (with and without conflict), had a higher self-esteem.

\section{Discussion}

Adolescents are often confused about their role and are torn between their responsibilities as growing adults and their desires as children. Family relationships are also altered as the process of differentiation begins to take place. As a result, the parent-adolescent relationship experiences increased conflict and decreased closeness (Steinberg \& Morris, 2001).

\section{Frequency \& intensity of parent adolescent} conflict

The current study found that the frequency of parents-adolescent conflict was higher during early adolescence but conflict intensity wasn't severe. These results were consistent with the study of Smetana et al., (2006) \& Pajkic Ivana, (2013) who found that the parent-adolescent conflict was higher during early adolescence. Also, conflict more frequent between adolescents and their parents but intensity of conflict was usually not intense.

These results concurrent with Melching, (2011) who stated that; early adolescence is characterized by multiple physical, emotional, and intellectual changes associated with puberty. So, this age is better associated with conflict frequency and conflict intensity.

The findings of the current study found that the most common issue conflict involves in the everyday events of family life as; bedtime, cleaning bedroom, performing homework, arranging clothes, watching TV or using social media, making too much noise at home, fighting with brothers and sisters, allowance, friends should they have and selection of new clothes, These results were consistent with Smetana et al., (2006), Santrock, (2006), Çopur et al., (2007), Ozmete Emine \& Bayoglu Ayse, (2009), \& Pajkic Ivana, (2013).

This may be due to the preoccupation of adolescents with advanced technology who spent most of their time using social media and watching TV. So, they wasted their time and delayed the daily activities as cleaning the bedroom, arranging clothes and delaying sleep time. This is supported by Shah et al., (2016) who mentioned that the main cause of the conflict was using of social media via a website or mobile. In the same line Blease, (2015), \& Griffiths et al., (2016) indicated that using the internet frequently and depressing the Facebook were two factors that commonly increase conflict in young age children.

Gongala Sagari, (2017), stated that young adults in their viewpoint need to say: "I'm growing and I can take care of myself". While the viewpoint of parents 
isn't the same. Parents realize that their young adults require extra care at this critical age. They are afraid that their children delaying homework and obtaining low scores at school or a bad boy or girl will be a friend to the adolescent and can affect his way of thinking.

The findings of this study indicated that adolescents who fighting with brothers and sisters and/or making too much noise at home had more frequent conflict, these may be due to adolescents' children can face many emotional and behavioral problems. This is normal changes for them at this time and they have mood swings are common among them (Gongala Sagari, 2017).

As children reach adolescence, period they often ask for more freedom. Parents walk a tightrope between wanting their children to be confident and able to do things for themselves and knowing that the world can be a frightening place with fears to their children's health and safety (Pickhardt, 2011). In addition, the amount of allowance for the adolescent child can also be a factor that increases the incidence of parentadolescent conflict. Adolescent dressing, hairstyle, and sense of fashion also change, mostly to something that parents may not approve of.

Regarding the topics of using drugs, drinking beer and smoking/spit tobacco, the culture and religion in our society prevent and prohibit it. While bothering parents when they want to be left alone and bothering adolescents when they want to be left alone didn't cause any conflict between adolescents and their parents. This may be explained that adolescents were satisfied when they were left home alone, felt free, practicing their hobbies without any restrictions. These results were in agreement with, Riesch et al., (2000), Ozmete Emine \& Bayoglu Ayse, (2009) \& Pajkic Ivana, (2013).

As regard, the topics of buying games and other things, going on dates and earning money away from the house. The study subjects mentioned that their parents buy games or other things to them. Also, they bring them to their school or special classes so these topics didn't cause a frequent conflict between adolescents and their parents. This is in agreement with Renk and Simpsom, (2005) who stated that conflicts over topics as religious, political, or social occur less frequently they considered it as sensitive topics (e.g., substance use, dating, and drinking beer or alcohol).

Relationships between parent-adolescent conflicts \& school achievement

The study results showed that there was a significant difference between parent-adolescent conflict and school achievement, the higher the school achievements, the more frequency of conflict occur, This result disagree with a study of (Branje, 2009), who reported a negative association between parentadolescent conflict and adolescent school performance and the same results reported by Onongha, (2015) who found that students with low school achievement have more conflict with their parents than students who have high performance. This result may be due to parent conflicts consider positive stress that motivate adolescent to achieve higher school level. Moreover, students' school excellence is the main target for parents which cause parents conflict who exerted pressure on their adolescents to do their best. This was in agreement with Nebel-Schwalm, (2006) who found that parentadolescent conflict would be more highly correlated with school achievement. A study by Shibeshi, (2015) indicated that school issue is the leading major source of conflict. Also, Onongha, (2015) stated that school achievement may be a cause of stress and conflict in families as conflict can arise when adolescent wasn't doing as well in school as their parents would like.

Relationships between parent-adolescent conflicts \& self-esteem

Deshpande \& Chhabriya, (2013) stated that due to the generation gap between parents and their adolescents and inability of parents to appreciate their adolescents, conflicts develop. Results of the current study reported that more than half of adolescents have conflict, their self-esteem are high, this result in agreement with Deshpande \& Chhabriya (2013) \& Driscoll (2013) who reported, mild punishment from parents can result in high self-esteem in adolescents' as they view their parents as their caretaker and sometimes protector. This could be interpreted that, the adolescence is in a tough time and there were various changes that adolescent have to deal with ranging from their body to the relationships they have with their friends.

Relationships between adolescents \& their parent characteristics \& Parent-Adolescent Conflicts

The present study found that there is a significant positive correlation between residence and parents' adolescent conflict, More than half of studied children comes from rural areas and highly educated parents either secondary, university or higher. This can be explained that, highly educated parents in Upper Egypt especially in rural areas insist on and compare their children with peers and their cousins to get high marks at school to satisfy their parents. Furthermore, there was a statistically negative correlation between gender of the studied adolescent and parents- adolescent conflict, male sex appears to have more conflict with their parents than do female. In line with this Wohabie (2007) \& Renk \& Simpsom (2005), found that female conflict was more frequent than male. 
Also, there is a highly statistically negative correlation between adolescents' ages and school grades (levels) of the studied adolescents as regard the parents-adolescent conflict, the lower the age and school grades, the higher of parent-adolescent conflict. This result is consistent with Helland et al., (2017) \& Whiteman et al., (2007) who stated that conflict between parents and adolescents increases and peaks during the early years of adolescence and is associated with the onset of puberty

The current study showed that there is a statistically positive correlation between birth order and parentsadolescent conflict, it was found that adolescents who were in the first birth order had the highest parentadolescent conflict. This finding was in the same line with the Findings of Helland et al., (2017), Shanahan et al., (2007), Whiteman et al., (2003), who indicate that parent-adolescent conflicts are generally high during the adolescent transition of the firstborn child, compared with that of younger siblings. However, there is a negative correlation between the child's chronic illness and parentsadolescent conflict, the child who has a chronic illness, he /she had experience conflict less frequently, this can be interpreted that parents of a child with chronic illness strive to satisfy their children's needs.

\section{Conclusion}

Based on the current study findings it was concluded that the majority of adolescents had higher frequency of conflict issues but intensity of conflict wasn't sever. Parent-adolescent conflict-had a positive effect on adolescent school achievement. There was no statistically significant relation between the adolescents' self-esteem and parent-adolescent conflict. But a statistically positive relation was found between higher score of school achievement of adolescent with and without conflict and self-esteem. The following factors were associated with higher frequency of conflict; rural area, first births, age at 14-15 years, first grade, male gender, housewife mothers and adolescent who live with either their father or mother.

\section{Recommendations}

- Parents should be aware of physical, cognitive and psychosocial changes and needs of adolescence period to deal with their children positively.

- Implementing an educational program about parent-adolescent conflicts to include parents and adolescents viewpoints about conflict.

- Health education to the parents about how to deal with adolescents' conflict and manage it.
- Encourage parents to respect their adolescent and keep their autonomy and should give them some freedom with supervision.

- Psychologists and social workers in schools to advise the adolescent students about positive interpersonal relationships as regard family issues.

- Periodical assessment should be done for selfesteem to all children in schools for early detection and management of any problem.

- 7- Further study needed to take the views of both parents and adolescents separately about the most issues that cause conflict and comparing points of view.

\section{References}

1. Allison, B., \& Schultz, J., (2004): Parentadolescent conflict in early adolescent. Adolescence, 39 (153): 101-119.

2. American Nurses Association \& Society of Pediatric Nurses (2003): Scope and standards of pediatric nursing practice. Washington, D.C: Author.

3. Bin Yaacob Mohd Jamil (2006): Parentadolescent relationships and its association to adolescents' self-esteem. Malaysian Journal of Medical Sciences, Vol. 13, No. 1, Januari (2124). Submitted-6.11.2004, Accepted-15.10.2005 pp 21-24.

4. Blease, C., (2015): Too many 'Friends,' too few 'Likes'? Evolutionary psychology and 'Facebook depression. Rev. Gen. Psychol. 19 (1), 1-13.

5. Branje Susan J., Doorn Muriel van, Valk Inge van der, Meeus Wim (2009): Parent-adolescent conflicts, conflict resolution types, and adolescent adjustment. Journal of Applied Developmental Psychology 30, 195-204. Contents lists available at ScienceDirect

6. Çopur, Z., Erkal, S., \& Afak (2007): Annelerin 12 ya_üzeri cocuklarıyla iliskilerinde yasadıkları catısmaların incelenmesi. Hacettepe Universitesi Sosyolojik Arastırmalar e-dergisi. Available Online at: http://www.sdergi.hacettepe.edu.tr/makaleleler_c erceve.htm.

7. Deshpande, A., Chhabriya, M., (2013): Parenting Styles and its Effects on Adolescents' Self-Esteem. vol 2.0 (2). 163-176.

8. Dornbusch, S., Ritter, P., Leidermann, P., Roberts, D., \& Fraleigh, M., (1987): The relation of parenting style to adolescent school performance. Child Development, 58, 12441257.

9. Driscoll, L., (2013): Parenting Styles and SelfEsteem. Scripps Senior Theses. Paper 155. 
retrieved

from:

http://scholarship.claremont.edu/scripps_theses/1 55

10. Elemary Fatma M., Al Omari Omar, Wynaden Dianne. (2016): The perception of adolescents' inter-parental conflict and accompanied emotional security: A descriptive study. Journal of Nursing Education and Practice, Vol. 6, No. 5. http://jnep.sciedupress.com DOI: 10.5430/jnep.v6n5p84 URL: http://dx.doi.org/10.5430/jnep.v6n5p84

11. Gongala Sagari (2017): 11 Common Problems Of Adolescence And Their Solutions. ON JANUARY 9, 2017. Available at: http://www.momjunction.com/articles/problemsof-adolescence_00381378/\#gref

12. Griffiths, M., Kuss, D., Billieux, J., Pontes, H., (2016): The evolution of Internet addiction: a global perspective. Addict. Behav. 53, 193-195.

13. Helland Maren S., \& Kjeldsen Anne Soest Tilmann von \& Røysamb Espen, Gustavson Kristin \& Nilsen Wendy (2017): Parental Child-Rearing Conflicts Through Adolescence: Trajectories and Associations With Child Characteristics and Externalizing Patterns. JOURNAL OF RESEARCH ON ADOLESCENCE, 1-13

14. Kouros C., Cummings E., Davies P., (2010): Early trajectories of interparental conflict and externalizing problems as predictors of social competence in preadolescence. Development and Psychopathology; 22(03): 527-37. PMid:20576176. Available at: http://dx.doi.org/10.1017/S0954579410000258

15. Lerner R., Steinberg L., (2004): The scientific study of adolescence: Past, present, and future. In: Lerner R, Steinberg L, editors. Handbook of adolescent psychology. 2. New York: Wiley. pp. $1-12$.

16. Melching Jessica A., (2011): Exploring ParentAdolescent Conflict: An Examination of Correlates and Longitudinal Predictors in Early Adolescence. University of New Orleans Theses and Dissertations. Paper 1396. Follow this and additional works at: http://scholarworks.uno.edu/td A Thesis Submitted to the Graduate Faculty of the University of New Orleans in partial fulfillment of the requirements for the degree of Master of Science in Psychology by Jessica Anne Melching B.A. University of Kentucky, 2006 December, 2011

17. Nebel-schwalm, M., (2006): The Relationship between Parent-Adolescent Conflict and
Academic Achievement; Louisana State University: unpublished Thesis.

18. Onongha Grace Igaba (2015): Influence of Parent-Adolescent Conflict on Adolescent Academic Performance in Oriade Local Government Area, Osun State, Nigeria. International Journal of Educational Research and Information Science 2015; 2(4): 61-66 Published online September 22, 2015. Available at: (http://www.openscienceonline.com/journal/eris)

19. Ozmete. E., \& Bayoglu, A., (2009): ParentYoung Adult Conflict: A Measurement on Frequency and Intensity of Conflict Issues; The Journal of International Social Research Vo.2 No.8

20. Pickhardt Carl E., (2011): Parents, Adolescents, and the Nature of Conflict Conflict is how parents and adolescent need to get along. Posted Oct 24, 2011. Available at: https://www.psychologytoday.com/blog/survivin g-your-childs-adolescence/ 201110/parentsadolescents-and-the-nature-conflict

21. Pajkic Ivana (2013): Impact of parentadolescent conflict on adolescents' well-being. Doctor of Philosophy. (B.A.Psych, PostGradDip. ApplPsych, M.A.Psych). Division of Psychology. School of Health Sciences. RMIT University. December.

22. Pinquart, M., \& Silbereisen, R., (2002): Changes in adolescents' and mothers' autonomy and connectedness in conflict discussions: An observation study. Journal of Adolescence, 25, 509-522.

23. Prinz, R., Foster, S., Kent, R., \& O'Leary, K., (1979): Multivariate assessment of conflict in distressed and non-distressed mother adolescent dyads. Journal of Applied Behavior Analysis, 12, 691-700.

24. Renk, K., Liljequist, L., Simpson, J., \& Phares, V., (2005): Gender and age differences in the topics of parent-adolescent conflict. The Family Journal, 13(2), 139-149. Doi:10.1177/1066480704271190

25. Riesch Susan K., Bush Loretta, Nelson Catherine J., Ohm Bonnie J., Portz Patricia A., Abell Barbara, Wightman Malissa R., \& Jenkins Patricia (2000): Topics of Conflict Between Parents and Young Adolescents. JSPN Vol. 5, NO.1 , Jan ary-March2,0 0027

26. Robin A., Foster S., (1989): Negotiating ParentAdolescent Conflict: A Behavioral-Family Systems Approach. New York, NY: Guilford Press. 
27. Rosenberg, M., (1965): Society and the Adolescent Self-Image. Princeton, New Jersey: Princeton University Press.

28. Santrock, J., (2006): Life-span Development.(10thed.).New York: McGraw Hill Company, Inc.

29. Shah Ruchita, Chauhan Nidhi, Gupta Anoop Krishna, Sen Mahadev Singh (2016): Short communication Adolescent-parent conflict in the age of social media: Case reports from India *, Department of Psychiatry, Postgraduate Institute of Medical Education and Research, Chandigarh 160012, India. Asian Journal of Psychiatry 23 (2016) 24-26 Contents lists available at ScienceDirect Asian Journal of Psychiatry journal home page : www.elsevier.com/locat e/ajp

30. Shanahan, L., McHale, S., Osgood, D., \& Crouter, A. (2007): Conflict frequency with mothers and fathers from middle childhood to late adolescence: Within- and between-families comparisons. Developmental Psychology, 43(3), 539-550. Doi:10.1037/0012-1649.43.3.539

31. Shearman, S. \& Dumlao, R. (2008): A crosscultural comparison of family communication patterns and conflict between young adults and parents. Journal of Family Communication, 8(3), 186-211. Doi:10.1080/15267430802182456

32. Shehata, A., \& Ramadan, F., (2010): Patterns of relationships and daily interactions between Parents and adolescents; Journal of AmericanScience;6(9).University of Alexandira.

33. Shibeshi Haftu Zinabie (2015): Sources of Conflict between Parents and Adolescents: In Dejach Belay Zeleke Secondary School. A Thesis Submitted to the Graduate Studies in Partial Fulfillment of Requirements for Master Degree in Developmental Psychology. Addis Ababa University College of Education And Behavioral Studies School of Psychology June 2015.

34. Smetana, J., Campione-Barr, N., \& Metzger, A., (2006): Adolescent development in interpersonal and societal contexts. Annual Review of Psychology, 57(1), 255-284. Doi:10.1146/annurev.psych.57.102904.190124

35. Steinberg, L., \& Morris, A., (2001): Adolescent development. Annual Review of Psychology, 52, 83-110.

36. Steinberg, L., \& Silk, J., (2002): Parenting adolescents (Ch. 4). In M. Bornstein (Ed).Handbook of parenting: Vol. 1. Children and parenting (pp. 103-133). Mahwah, NJ:Erlbaum.

37. United Nations International Children's Emergency Fund [UNICEF]. Adolescence.
(2011). Available from: http://www.unicef.org/e gypt/children_151.html

38. Unger, D., Brown, M., Tressell, P., \& McLeod, L., (2000): Interparental conflict and adolescent depressed mood: The role of family functioning. Child Psychiatry and Human Development, 31(1), 23-41.

39. Wingate, E.A.(2004): Attribution Process in Mother-Adolescent Conflict. Unpublished Thesis; B.S., University of Louisiana-Lafayette

40. Whiteman, S., McHale, S., \& Crouter, A., (2003): What parents learn from experience: The first child as a first draft? Journal of Marriage and Family, 65, 608-621. doi:10.1111/j.17413737.2003.00608.x

41. Whiteman, S., McHale, S., \& Crouter, A., (2007): Longitudinal changes in marital relationships: The role of offspring's pubertal development. Journal of Marriage and Family, 69, 1005-1020. doi:10.1111/j.1741-3737.2007. 00427.x CHILD-REARING CONFLICT TRAJECTORIES 13

42. Wohabie B., (2007): Parent-Adolescent Conflict: Major Issues and Determinants. Addis Ababa University: unpublished Thesis. 